Scientia Marina 70 (2)

June 2006, 311-318, Barcelona (Spain)

ISSN: 0214-8358

\title{
Phylogenetic relationships of Mediterranean Mullidae species (Perciformes) inferred from genetic and morphologic data
}

\author{
CEMAL TURAN
}

Fisheries Genetics Laboratory, Faculty of Fisheries and Aquaculture, Mustafa Kemal University, 31040 Antakya, Hatay, Turkey.E-mail: cturan@mku.edu.tr

\begin{abstract}
SUMMARY: Genetic and morphological divergence and phylogenetic relationships of four species Mullus barbatus, Mullus surmuletus, Upeneus moluccensis, Upeneus pori and one subspecies M.b. ponticus of Mullus were investigated using 12 enzymatic systems, corresponding to 17 putative loci. Eight loci $\left(A A T-1^{*}, A A T-2^{*}, A D H^{*}, G A P D H^{*}, G 6 P D H^{*}, I D H P^{*}\right.$, $\left.P G I-2^{*}, S O D^{*}\right)$ were found to be polymorphic in at least one species, while the remaining nine (mAAT*, $C K-1^{*}, C K-2^{*}$, $\left.G 3 P D H^{*}, M D H^{*}, M E-1^{*}, M E-2^{*}, P G I-1^{*}, P G M^{*}\right)$ were monomorphic in all species. Several loci showed different electrophoretic patterns among species and thus can be used in species taxonomy as diagnostic markers. The $P G M^{*}$ and $S O D^{*}$ loci proved to be especially species-specific. Fisher's exact test revealed overall highly significant allele frequency differences between $M$. barbatus and $M . b$. ponticus $(P<0.001)$. Pairwise comparisons of genetic distance were found to be 0.034 between M. barbatus and M. b. ponticus, and 0.341 between M. barbatus and M. surmuletus within the genus Mullus. Relatively higher genetic differentiation $(D=0.628)$ was observed between $U$. moluccensis and $U$. pori. For intergeneric comparisons, the highest genetic distance (1.250) was detected between M. surmuletus and $U$. pori, and the lowest $(D=1.056)$ was observed between M. surmuletus and U. moluccensis. Remarkably U. pori was genetically the most distinct species from the genus Mullus. A neighbour-joining analysis of genetic data separated the two genera: M. barbatus and M. b. ponticus clustered as the closest taxonomic assemblage, which was a sister group to M. surmuletus in the first branch, while U. moluccensis and $U$. pori clustered more divergently in the second branch. Morphological data using meristic characters was congruent with the genetic data and revealed similar patterns of relationships among four Mullidae species.
\end{abstract}

Keywords: Mullidae, genetic, morphology, phylogeny.

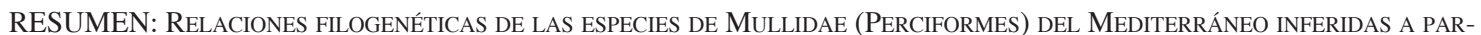
TIR DE DATOS GENÉTICOS Y MORFOLÓGICOS. - Se investigaron las divergencias genéticas y morfológicas y las relaciones filogenéticas de cuatro especies Mullus barbatus, Mullus surmuletus, Upeneus moluccensis, Upeneus pori y una subespecie $M$. b. ponticus, usando 12 sistemas enzymáticos, correspondientes a 17 loci putativos. Se encontró que 8 loci (AAT-1*, AAT-2*, $\left.A D H^{*}, G A P D H^{*}, G 6 P D H^{*}, I D H P^{*}, P G I-2^{*}, S O D^{*}\right)$ eran polimórficos, en al menos una especie, mientras que los 9 restantes $\left(m A A T^{*}, C K-1^{*}, C K-2^{*}, G 3 P D H^{*}, M D H^{*}, M E-1^{*}, M E-2^{*}, P G I-1^{*}, P G M^{*}\right)$ eran monomórficos en todas las especies. Varios loci mostraron diferentes patrones electroforéticos entre especies y por tanto pueden utilizarse como marcadores diagnóstico en taxonomía específica. Los loci $P G M^{*}$ y $S O D^{*}$ fueron especie-específicos. El "Fisher's exact test" reveló diferencias altamente significativas totales de la frecuencia de alelos entre M. barbatus and M. b. ponticus $(P<0.001)$. La comparación de distancia genética por parejas fue de 0.034 entre $M$. barbatus y $M$. b. ponticus, y 0.341 entre $M$. barbatus y M. surmuletus, dentro del género Mullus. Se observó una diferenciación genética $(D=0.628)$ relativamente mayor entre $U$. moluccensis y U. pori. Para las comparaciones entre géneros, la distancia genética más alta (1.250) se detectó entre $M$. surmuletus y $U$. pori, y la más baja $(D=1.056)$ fue observada entre $M$. surmuletus y $U$. moluccensis. Remarcablemente, $U$. pori fue genéticamente la especie con mayor diferencia respecto del género Mullus. El árbol filogenético construido mediante el análisis "neighbor-joining" de los datos genéticos, separó los dos géneros: M. barbatus y M. b. ponticus, que se agruparon como grupos taxonómicos próximos. Estos fueron grupos "hermanos" de $M$. surmuletus en la primera rama, mientras que $U$. moluccensis y $U$. pori se agruparon con mayor divergencia en la segunda. La utilización de caracteres merísticos fue congruente con los datos genéticos y reveló un patrón similar de relación entre las cuatros especies de Mullidae.

Palabras clave: Mullidae, genética, morfología, filogénia. 


\section{INTRODUCTION}

The family Mullidae is a commercially important demersal fish group distributed throughout the world's seas. It consists of 15 genera of which only Mullus, Upeneus and Pseudopeneus inhabit the Mediterranean Sea (Hureau, 1986; Golani, 1994). The genus Mullus is represented by two species (Mullus barbatus and Mullus surmuletus) and one subspecies (Mullus barbatus ponticus). M. barbatus L., 1758 is a benthic species, found mainly on muddy and sandy bottoms, distributed throughout the Mediterranean, as well as in the eastern Atlantic, from the British Islands in the north to Senegal in the south (Hureau, 1986). M. barbatus in the Black Sea is taxonomically classified as a subspecies Mullus barbatus ponticus Essipov, 1927 (Rassa, 1983; Hureau, 1986; www.fishbase.org). There have been several biological and traditional taxonomic studies on M. b. ponticus (Rassa, 1983; Hureau, 1986; Sahin and Akbulut, 1997; Mikhov, 2000). However, there is no genetic study to support the present taxonomic status of $M . b$. ponticus. Mullus surmuletus L., 1758 is a benthic fish inhabiting deep rocky and sandy bottoms. It is distributed throughout the Mediterranean Sea, in the Atlantic, from Norway to the Canary Island, in the Black Sea and in the north-western coasts of Africa. There are two species (Upeneus moluccensis and Upeneus pori) of the genus Upeneus in the Mediterranean Sea. $U$. moluccensis (Bleeker, 1855) is a lessepsian migrant species and is found in the Indo-Pacific region to the northern coasts of Australia, and also westward to East Africa. After the opening of the Suez channel (1869), U. moluccensis entered the eastern Mediterranean (northward to Aegean Sea) and now inhabits benthic and tropical inshore waters. Kosswig (1950) was the first to report $U$. moluccensis (Ben-Tuvia and Golani 1989) in the Mediterranean Sea. U. pori is also a lessepsian migrant species which penetrates into the Mediterranean Sea through the Suez Channel (Ben-Tuvia and Golani, 1989) and inhabits the western Indian Ocean: from the Red Sea to southern Oman. This species was first recorded by Kosswig (1950) as Upenoides (Upeneus) tragula in the eastern Mediterranean (Iskenderun Bay). Upeneus pori was also misclassified as Upeneus tragula and Upeneus vittatus (Fischer et al., 1987; CIESM 2002), and some information about this species was given under this name (Hureau, 1986). The Pseudopeneus genus is repre- sented with Pseudopeneus prayensis (Cuvier, 1829) found in the eastern Atlantic: Morocco to Angola.

The classification of Mullidae was mainly based on morphological characters (Tortonese, 1975; Nelson, 1984; Hureau, 1986; Golani, 1994). Currently, a number of studies on genetic inferences between species and genera in the family Mullidae in the Mediterranean Sea have been published. Cammarata et al. (2002) analyzed biochemical taxonomic differentiation between $M$. barbatus and $M$. surmuletus. Mamuris et al. (1998) examined genetic protein variation between $M$. barbatus and M. surmuletus populations. Mamuris et al. (1999a) and Apostolidis et al. (2001) investigated the genetic relationship of four mullet species (U. moluccensis, $P$. prayensis, M. barbatus and M. surmuletus).

Several publications have given detailed information about the distribution and the identification characteristics of $U$. pori (Hureau, 1986; Fischer et al., 1987; Aksiray, 1987; CIESM, 2002). The phylogenetic relationship of $U$. pori within the family Mullidae has not yet been stated. Moreover, there has been no genetic attempt to support the present taxonomic status of $M$. b. ponticus within the family Mullidae.

A central challenge with respect to marine species is to understand patterns of genetic differentiation. Allozyme polymorphisms have commonly been used for phylogenetic inferences in various fish species (Exadactylos and Thorpe, 2001; Cammarata et al., 2002; Konishi et al., 2003; Swartz et al., 2004; Turan et al., 2005). In the present study the pattern of phylogenetic relationships of two genera, including four species, $M$. barbatus, M. surmuletus, $U$. moluccensis, $U$. pori, and one subspecies, M. $b$. ponticus, living in the Mediterranean Sea, were investigated together with genetic and morphological characters. The main aims of the present study were: firstly, to find the degree of genetic divergence between $M$. barbatus and $M$. b. ponticus to elucidate the subspecies status of $M . b$. ponticus; and secondly, to make a preliminary study of the phylogenetic status of $U$. pori within the family Mullidae.

\section{MATERIAL AND METHODS}

\section{Sampling}

Specimens of $M$. barbatus $(\mathrm{n}=35)$, M. surmuletus $(\mathrm{n}=35)$, and $U$. moluccensis $(\mathrm{n}=35)$ were collected 


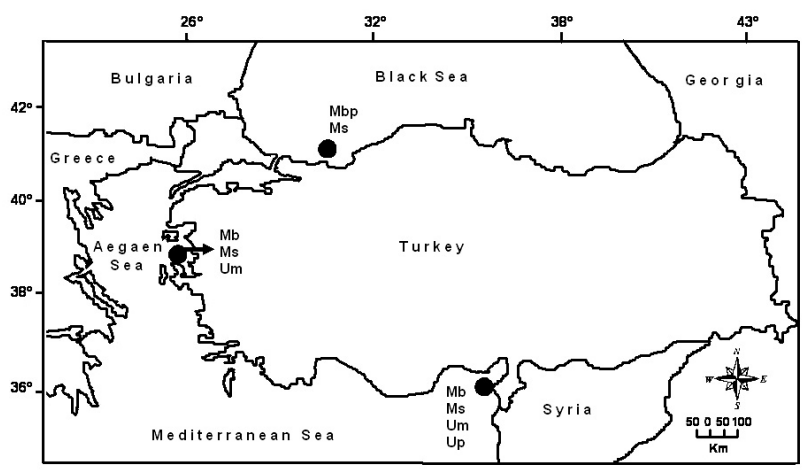

FIG. 1. - Map of sampling locations for each Mullidae species. The abbreviations of species are in the figure: Mullus barbatus, Mb; Mullus barbatus ponticus, Mbp; Mullus surmuletus, Ms; Upeneus moluccensis, Um; Upeneus pori, Up.

from Iskenderun Bay in the Mediterranean Sea (Fig. 1). Twenty specimens of different populations of the same species were collected from the Aegean Sea (Izmir Bay) and Black Sea (Zonguldak) using commercial trawlers. $M$. $b$. ponticus lives in the Black Sea, and $U$. pori lives in the north-eastern Mediterranean Sea. Therefore, M. b. ponticus $(\mathrm{n}=55)$ and $U$. pori $(\mathrm{n}=55)$ specimens were only sampled from the Black Sea (Zonguldak) and northeastern Mediterranean Sea (Iskenderun Bay) respectively (Fig. 1). Samples were collected between the years 2003 and 2004. All specimens arrived in ice at the laboratory, where samples were placed individually into plastic bags and stored at $-20^{\circ} \mathrm{C}$ until examined. Muscle tissue samples were dissected quickly on the lateral line for allozyme.

\section{Allozyme}

Standard horizontal starch gel electrophoresis was carried out as described by Moritz and Hillis (1990). The nomenclature used to designate loci and alleles was that proposed by Shaklee et al. (1990). After an enzyme screening program, twelve enzymes comprising seventeen putative loci that produced well-resolved staining patterns consistent with known enzyme sub-unit structure were routinely examined. The enzymes used were: aspartate aminotransferase $\left(A A T^{*}\right.$, E.C. 2.6.1.1), alcohol dehydrogenase $\left(A D H^{*}\right.$, E.C. 1.1.1.1), creatine kinase ( $C K^{*}$, E.C. 2.7.3.2), glyceraldehyde-3-phosphate dehydrogenase $\left(G A P D H^{*}\right.$, EC 1.2.1.12), glycerol-3-phosphate dehydrogenase $\left(G 3 P D H^{*}\right.$, E.C. 1.1.1.8), glucose-6-phosphate dehydrogenase (G6PDH*, EC 1.1.1.49), isocitrate dehydrogenase (IDHP*, E.C. 1.1.1.42), malate dehydrogenase
$\left(M D H^{*}\right.$; E.C. 1.1.1.37), malic enzyme $\left(M E^{*}, \mathrm{EC}\right.$ 1.1.1.40), phosphoglucose isomerase (PGI*, E.C. 5.3.1.9), phosphoglucose mutase $\left(P G M^{*}\right.$, E.C. 5.4.2.2), superoxide dismutase (SOD*, E.C. 1.15.1.1). Alleles were scored according to their mobility relative to the most commonly observed allele which was designated as $* 100$. All calculations were performed using TFPGAv1.3 (Miller, 1997) and PHYLIP (Felsenstein, 1993) computer packages. Nei's (1978) genetic distance $(D)$ and identity $(I)$ were calculated using allele frequency data. A locus is considered polymorphic if the frequency of the most common allele does not exceed $0.99\left(\mathrm{P}_{0.99}\right)$ or $0.95\left(\mathrm{P}_{0.95}\right)$. Nei's genetic distances were used to estimate genetic relationships between species using the neighbour-joining (Saitou and Nei, 1987) method. Robustness of nodes in the neighbour-joining tree was evaluated by bootstrapping over samples (Felsenstein, 1985).

\section{Morphology}

Meristic characters commonly used to describe the Mullidae species were used for morphological analysis. The number of unbranched and branched rays on the first dorsal fin (DFR1), second dorsal fin (DFR2), ventral fin (VFR), anal fin (AFR), pectoral fin (PFR), gill rakers (GR) and scales in a lateral line (LS) under a binocular microscope were recorded. Vertebra numbers (VN) were counted after taking $\mathrm{X}$-ray films of fish. Hierarchical cluster analysis using squared Euclidean distances was performed, and the neighbour-joining method was used to estimate phenotypic relationships between species. Prior to analysis, size effect (allometry) in the data set was checked for all meristic characters and no significant linear correlation $(\mathrm{P}>0.05)$ between any meristic character and the standard length of fish was found, therefore actual counts were used in the analyses. Morphological analyses were performed using SPSS $v 13$, SYSTAT $v 11$ and Splits Tree $v 4$ program packages.

\section{RESULTS}

\section{Allozyme}

At all loci, staining of gels produced bands for all species. The allele frequencies of polymorphic loci in the species are given in Table 1. Eight loci (AAT- 
TABLE 1. - Allele frequencies at polymorphic loci in the four Mullidae species. n, sample size. Ho, observed heterozygosity (direct count); He, Hardy-Weinberg expected heterozygosity. Monomorphic loci for all species were not given in the Table.

\begin{tabular}{|c|c|c|c|c|c|c|}
\hline Locus & Alleles & M. barbatus & M. b. ponticus & M. surmuletus & U. moluccensis & U.pori \\
\hline$n$ & & 55 & 55 & 55 & 55 & 55 \\
\hline \multirow[t]{2}{*}{$m \mathrm{AAT}^{*}$} & $\begin{array}{l}100 \\
143\end{array}$ & 1.00 & 1.00 & 1.00 & & \\
\hline & 156 & & & & 1.00 & 1.00 \\
\hline \multirow[t]{5}{*}{ AAT-1* } & 65 & & 0.07 & & 1.00 & \\
\hline & 80 & & & & 1.00 & \\
\hline & 100 & 1.00 & 0.93 & 0.94 & & \\
\hline & $\begin{array}{l}120 \\
130\end{array}$ & & & 0.04 & & \\
\hline & $\begin{array}{l}130 \\
144\end{array}$ & & & 0.02 & & 1.00 \\
\hline \multirow[t]{3}{*}{ AAT- $2 *$} & 100 & 0.76 & 0.80 & 0.75 & 1.00 & 1.00 \\
\hline & 115 & 0.24 & 0.17 & 0.25 & & \\
\hline & 128 & & 0.03 & & & \\
\hline \multirow[t]{5}{*}{$\mathrm{ADH}^{*}$} & 100 & 0.87 & 0.88 & 1.00 & & \\
\hline & 135 & 0.07 & 0.12 & & & \\
\hline & 150 & 0.06 & & & & \\
\hline & 180 & & & & 0.10 & \\
\hline & 195 & & & & 0.90 & 1.00 \\
\hline \multirow[t]{2}{*}{$\mathrm{CK}-2^{*}$} & 100 & & & & 1.00 & 1.00 \\
\hline & 135 & 1.00 & 1.00 & 1.00 & & \\
\hline \multirow[t]{3}{*}{ GAPDH* } & 100 & 1.00 & 1.00 & 1.00 & & \\
\hline & 120 & & & & 1.00 & 0.97 \\
\hline & 135 & & & & & 0.03 \\
\hline \multirow[t]{3}{*}{ G3PDH* } & 80 & & & & & 1.00 \\
\hline & 100 & & & 1.00 & 1.00 & \\
\hline & 130 & 1.00 & 1.00 & & & \\
\hline \multirow[t]{4}{*}{ G6PDH* } & 75 & & & & & 1.00 \\
\hline & 87 & & & & 1.00 & \\
\hline & 100 & 0.95 & 0.25 & 1.00 & & \\
\hline & 125 & 0.05 & 0.75 & & & \\
\hline \multirow[t]{4}{*}{ IDHP* } & 100 & & & & 1.00 & \\
\hline & 122 & 0.10 & & 0.92 & & \\
\hline & 150 & 0.90 & 1.00 & 0.08 & & \\
\hline & 225 & & & & & 1.00 \\
\hline \multirow[t]{2}{*}{$\mathrm{MDH}^{*}$} & 100 & 1.00 & 1.00 & 1.00 & & \\
\hline & 200 & & & 100 & 1.00 & 1.00 \\
\hline \multirow{3}{*}{ PGI-2* } & $\begin{array}{l}100 \\
130\end{array}$ & & & 1.00 & 0.96 & 0.05 \\
\hline & 180 & 1.00 & 1.00 & & & \\
\hline & 230 & & & & 0.04 & 0.95 \\
\hline \multirow[t]{4}{*}{ PGM* } & 100 & & & & 1.00 & \\
\hline & 128 & & & 1.00 & & \\
\hline & 155 & 1.00 & 1.00 & & & \\
\hline & 200 & & & & & 1.00 \\
\hline \multirow[t]{4}{*}{ SOD* } & 50 & & & & 1.00 & \\
\hline & 73 & & & & & 1.00 \\
\hline & 87 & & & 1.00 & & \\
\hline & 100 & 1.00 & 0.81 & & & \\
\hline \multirow{4}{*}{$\begin{array}{l}\% \text { of loci } \\
\text { polymorphic }\end{array}$} & $P^{115}$ & 235 & $\begin{array}{l}0.19 \\
29.4\end{array}$ & 17.6 & 118 & 118 \\
\hline & $\mathrm{P}_{0}$ & 23.5 & 29.4 & 17.6 & 5.9 & 59 \\
\hline & $\mathrm{H}_{\mathrm{o}} \mathrm{I}_{0.95}$ & 0.037 & 0.027 & 0.031 & 0.016 & 0.009 \\
\hline & $\mathrm{H}_{\mathrm{e}}$ & 0.051 & 0.080 & 0.038 & 0.015 & 0.009 \\
\hline
\end{tabular}

$I^{*}, A A T-2^{*}, A D H^{*}, G A P D H^{*}, G 6 P D H^{*}, I D H P^{*}$, $\left.P G I-2^{*}, S O D^{*}\right)$ were found to be polymorphic in at least one species. The remaining 9 loci were monomorphic $\left(m A A T^{*}, C K-1^{*}, C K-2^{*}, G 3 P D H^{*}\right.$, $\left.M D H^{*}, M E-1^{*}, M E-2^{*}, P G I-1^{*}, P G M^{*}\right)$ in all species. Twelve loci $\left(m A A T^{*}, A A T-1^{*}, A D H^{*}, C K\right.$ $2^{*}, G A P D H^{*}, G 3 P D H^{*}, G 6 P D H^{*}, I D H P^{*}, M D H^{*}$, $P G I-2^{*}, P G M^{*}, S O D^{*}$ ) revealed unique alleles for each species and may be used as diagnostic loci. The
$P G M^{*}$ and $S O D^{*}$ loci proved to be especially species-specific. Results concerning the levels of intraspecific heterozygosity observed with allozymes revealed a relatively lower level of heterozygosity in $U$. pori $\left(H_{\mathrm{o}}=0.009 ; H_{\mathrm{e}}=0.009\right)$ and a relatively higher level in $M$. barbatus $\left(H_{\mathrm{o}}=0.037\right.$; $\left.H_{\mathrm{e}}=0.051\right)$. The percentage of polymorphic loci under the 0.95 criterion ranged from 5.9 in $U$. pori to 29.4 in $M$. b. ponticus. 
TABLE 2. - Values of the genetic distance based on 17 putative loci for all pairwise comparisons between the populations of sampled areas for each species as illustrated in

\begin{tabular}{lccc}
\hline Areas & M. barbatus & M. surmuletus & U. moluccensis \\
\hline $\begin{array}{l}\text { Mediterranean Sea - } \\
\text { Aegean Sea }\end{array}$ & 0.0011 & 0.0010 & 0.0015 \\
$\begin{array}{l}\text { Mediterranean Sea - } \\
\text { Black Sea }\end{array}$ & -- & 0.0012 & - \\
$\begin{array}{l}\text { Aegean Sea - } \\
\text { Black Sea }\end{array}$ & -- & 0.0014 & - \\
\hline
\end{tabular}

Fisher's exact test revealed overall highly significant allele frequency differences between $M$. barbatus and $M . b$. ponticus $\left(\chi^{2}=75.16 ; P<0.001\right)$. Allele frequencies differed significantly between the $M$. barbatus and $M . b$. ponticus samples for five out of the eight polymorphic loci $(A A T-2 *, \mathrm{P}<0.01$; $A D H^{*}, \mathrm{P}<0.05 ; G 6 P D H^{*}, \mathrm{P}<0.001 ; I D H P^{*}, \mathrm{P}$ $\left.<0.01 ; S O D^{*}, \mathrm{P}<0.001\right)$.

The three species were compared to elucidate population genetic variation in the data set. There were no significant genetic differences $(\mathrm{P}>0.05)$ between the samples of M. barbatus, M. surmuletus, and $U$. moluccensis collected from the three different seas (Table 2, Fig. 1). Nei's (1978) genetic distances $(D)$ between the populations were found to be low, and ranged from 0.0010 between the Mediterranean Sea and Aegean Sea populations of M. surmuletus to 0.0015 between the Mediterranean Sea and Aegean Sea populations of U. moluccensis (Table 2).

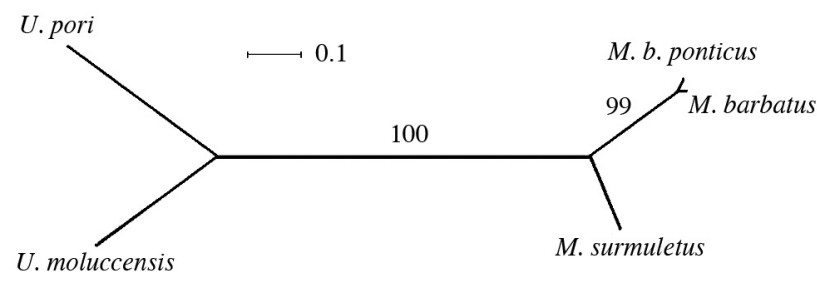

FIG. 2. - Neighbour-joining tree based on Nei's (1978) genetic distances for allozymes. Branch lengths are proportional to the genetic distances between taxa (see scale bar). Numbers on nodes indicate the bootstrap values for 1000 replications.

The pairwise comparison of genetic distance $(D)$ between the two congeneric species revealed that genetic divergence of $M . b$. ponticus from $M$. barbatus was 0.034 . Genetic distance between M. barbatus and M. surmuletus was found to be 0.341 (Table 3). Relatively higher genetic differentiation ( $D=0.628)$ was observed between the other congeneric species, $U$. moluccensis and $U$. pori.

For intergeneric comparisons, the highest $D$ value was 1.250 detected between $M$. surmuletus and $U$. pori, and the lowest (1.056) was found between $M$. surmuletus and $U$. moluccensis. U. pori seemed to be genetically the most distinct species from the Mullus genera.

Relationships between four species examined by the neighbour-joining analysis separated the two genera (Fig. 2). M. barbatus, M. b. ponticus and $M$. surmuletus clustered together in one group, while $U$. moluccensis and $U$. pori clustered in the second group. In the first branch, M. barbatus and $M . b$.

TABLE 3. - Nei's (1978) genetic distance based on 17 putative loci (below diagonal) and the squared Euclidean distances (above diagonal) for morphologic data.

\begin{tabular}{|c|c|c|c|c|c|}
\hline Species & M. barbatus & M.b. ponticus & M. surmuletus & U. moluccensis & $U \cdot$ pori \\
\hline M. barbatus & - & 335 & 683 & 1060 & 1289 \\
\hline M. b. ponticus & 0.034 & - & 554 & 944 & 1028 \\
\hline M. surmuletus & 0.341 & 0.398 & - & 1147 & 1450 \\
\hline U. moluccensis & 1.240 & 1.215 & 1.056 & - & 925 \\
\hline$U$. pori & 1.243 & 1.218 & 1.250 & 0.628 & - \\
\hline
\end{tabular}

TABLE 4. - Formula of observed meristic characters of the Mullidae species. Roman letters show spine rays. Standard deviations of mean standard length (MSL) are given in brackets. DFR1, first dorsal fin rays; DFR2, second dorsal fin rays; VFR, ventral fin rays; AFR, anal fin rays; PFR, pectoral fin rays; GR, gill rakers; LS, scales in a lateral line; VN, vertebra numbers.

\begin{tabular}{|c|c|c|c|c|c|c|c|c|c|}
\hline Species & DFR 1 & DFR 2 & VFR & AFR & PFR & GR & LS & VN & MSL \\
\hline M. barbatus & VIII & I 8 & I $4-5$ & I 6 & $16-17$ & $23-25$ & $33-35$ & 23 & $12.72(0.90)$ \\
\hline M.b. ponticus & VIII & I 8 & I 5 & I 6 & $16-17$ & $17-19$ & $32-34$ & $23-24$ & $11.8(1.01)$ \\
\hline M. surmuletus & VIII & I 8 & I 6-7 & I 6 & $16-17$ & $24-25$ & $32-36$ & 23 & $11.30(1.03)$ \\
\hline U. moluccensis & VIII & I 8 & I 5 & I 6 & $13-16$ & $25-27$ & $29-31$ & 23 & $9.96(0.53)$ \\
\hline U. pori & VII & I $7-8$ & I 5 & I $7-8$ & $15-16$ & $25-29$ & $33-34$ & $23-24$ & $9.53(0.68)$ \\
\hline
\end{tabular}




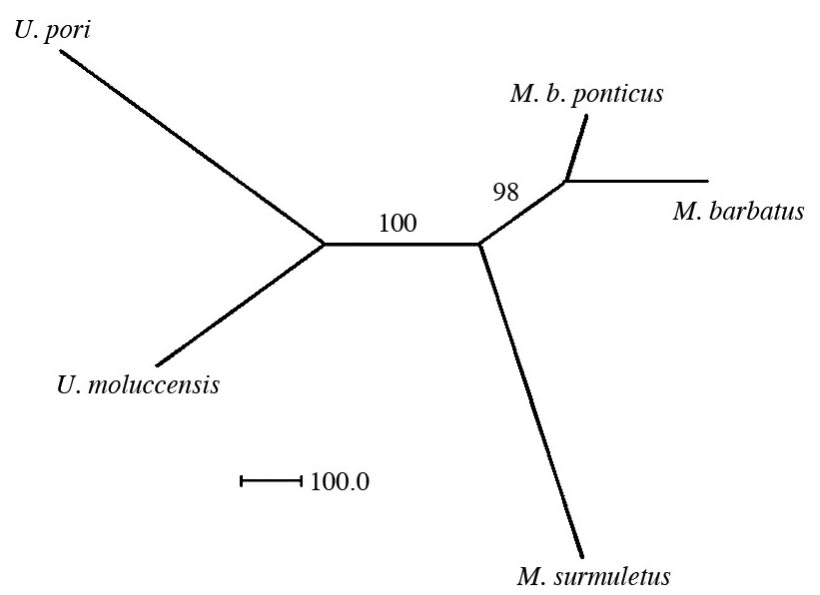

FIG. 3. - Neighbour-joining tree based on squared Euclidean distances. Scale bars represent the branch length. Numbers on nodes indicate the bootstrap values.

ponticus were the closest taxa and they were the sister group to $M$. surmuletus. High bootstrapping values were detected for each node on the tree, supporting the detected pattern of differentiation.

\section{Morphology}

The range of observed meristic characters (Table 4) of four Mullidae species were in the range of their description given by Hureau (1986). Univariate statistics (ANOVA) revealed highly significant $(P<0.001)$ differences between species for all meristic characters. Squared Euclidiean distances of morphologic data revealed that morphological divergence was higher within the genera Upeneus than within the genera Mullus (Table 3). The highest morphological divergences within the genera Mullus and Upeneus were 683 and 925, detected between $M$. barbatus and $M$. surmuletus, and between $U$. moluccensis and $U$. pori respectively. For intergeneric comparisons, the highest morphologic divergence was observed between $M$. surmuletus and $U$. pori, and the lowest was detected between $M$. barbatus and $M . b$. ponticus. In the neighbour-joining analysis based on the squared Euclidean distances, U. moluccensis and U. pori clustered as a sister taxon in one node, and in another node, $M$. barbatus and $M . b$. ponticus were the closest taxa and were the sister group of M. surmuletus (Fig. 3).

\section{DISCUSSION}

The present allozymic and morphologic analysis revealed a similar pattern of phylogenetic relation- ships between four Mullidae species. The phylogenetic analysis within the family Mullidae split the genera Mullus and Upeneus species into two main clusters. In the first group, M. barbatus and $M . b$. ponticus clustered as the closest taxa. The phylogenetic position of $M . b$. ponticus was considered in this study for the first time. The amount of genetic distance (0.034) of $M$. b ponticus is high for it to be considered as a Black Sea population of M. barbatus. Mamuris et al. (1998) reported the mean genetic distances (Nei, 1978) within M. Barbatus populations to be 0.0039. In a review, Shaklee et al. (1982) reported that Nei's genetic distance $(D)$ between nominal species of fishes ranged from only 0.025 to 0.60 , and averaged 0.30 . Therefore, the present genetic analysis may support the subspecies status of $M . b$. ponticus, and it also indicates that $M . b$. ponticus could be an incipient species within the genera Mullus.

Low genetic distances were observed within Mullus and Upeneus species. High genetic homogeneities between the populations of $M$. barbatus, $M$. surmuletus, and $U$. moluccensis were detected. Similar low genetic distances between populations of Mullus had already been reported in previous studies. Low genetic distances were found between eight populations of M. barbatus (0.0039) (Mamuris et al., 1998) and slightly larger distances between Mediterranean populations of M. surmuletus (0.011) (Mamuris et al., 1999b). Furthermore, the detected low genetic distance in the present study can also be attributable to the low sample size used for population comparisons. An increase in sample size may also increase the frequency of low occurring alleles at a given locus, which therefore may magnify allele frequency differences between samples.

In the congeneric comparisons, the detected genetic distance within the genera Mullus ranged from 0.341 between $M$. barbatus and M. surmuletus to 0.398 between $M$. b. ponticus and M. surmuletus. The present congeneric differentiation was little higher than those found by Mamuris et al. (1998) $(D=0.329)$ and Mamuris et al. (1999a) $(D=0.316)$. However, Cammarata et al. (2002) reported a relatively low genetic distance $(D=0.068)$, which may be related to the different allozyme loci examined or differences in experimental procedures.

The genetic distance between $U$. moluccensis and $U$. pori was higher $(D=0.628)$ than that found within the genus Mullus. Morphological divergence was also higher within the genera Upeneus than within the 
genera Mullus. The detected genetic distance between $U$. moluccensis and $U$. pori is within the limits cited by Shaklee et al. (1982). Therefore, the present genetic distance was enough to classify $U$. pori as a congeneric species, and support the current taxonomic status of $U$. pori within the genus Upeneus.

The amount of genetic distance found was enough to discriminate the samples as intergeneric species. The allozymic distance was higher between lineages than within the same lineage; the $D$ values among the non-congeneric species ranged from 1.056 to 1.250 when comparisons were made between the Mullus and Upeneus species. These divergences are within the limits cited by Avise and Aquadro (1982), who reported that the mean genetic distance (unweighted) for bony fishes is 1.13 between genera. The highest genetic distance ( $D=1.250)$ was detected between $M$. surmuletus and $U$. pori, and in general $U$. pori seems to be genetically more separated from the Mullus species. The detected amount of genetic distance for intergeneric comparisons is congruent with those reported by Mamuris et al. (1999a) regarding three intergeneric (U. moluccensis vs. M. barbatus and M. surmuletus; $D=1.023$ and 1.237 respectively) comparisons.

The phylogenetic trees produced in the present study are in general agreement with those presented by Mamuris et al. (1999a) and Apostolidis et al. (2001). The present research project is a preliminary investigation into the taxonomic status of $M . b$. ponticus as a subspecies within the genera Mullus and $U$. pori as a species within the genera Upeneus. The topology produced from the NJ tree for genetic and morphologic data supported the present taxonomic status of M. b. ponticus and $U$. pori.

In conclusion, the allozymic and morphologic data used in this study were congruent with the present monophyletic status of the Mullus and Upeneus genera. The degree of differentiation of $M . b$. ponticus from $M . b$. barbatus seems to be large enough to consider them as subspecies. The amount of genetic and morphologic divergence was higher within the Upeneus genera than within the Mullus genera, and $U$. pori was genetically the most distinct species within this family.

\section{ACKNOWLEDGEMENTS}

Thanks to the Scientific Research Foundation Unit of Mustafa Kemal University and TUBA for financial support, and M. Gurlek, S. Sevenler, D. Hazar, D. Yaglioglu for sampling and help in the Lab.

\section{REFERENCES}

Aksiray, F. - 1987. Marine fishes of Turkey and their key characteristics. Istanbul University Publications No: 3490, Istanbul, Turkey.

Apostolidis, A.P., Z. Mamuris and C. Triantaphyllidi. - 2001. Phylogenetic relationships among four species of Mullidae (Perciformes) inferred from DNA sequences of mitochondrial cytochrome b and16S rRNA genes. Biochem. Syst. Eco., 29: 901-909.

Avise, J.C. and C.F. Aquadro. - 1982. Comparative summary of genetic distances in the vertebrates-patterns and correlations. Evol. Biol., 15: 151-185.

Ben-Tuvia, A. and D. Golani. - 1989. A new species of goatfish (Mullidae) of the genus Upeneus from the Red Sea and the eastern Mediterranean. Isr. J. Zool., 36 (2): 105.

Cammarata, M., N. Parrinello and M. Arculeo. - 2002. Biochemical taxonomic differentiation between $M$. barbatus and $M$. surmuletus (Pisces, Mullidae). Comp. Biochem. Physiol., 99: 719-722.

Golani, D., L. Orsi-Relini, E. Massutí and JP. Quignard. - 2002. Atlas of Exotic Species in the Mediterranean. Fishes. CIESM Publishers, Monaco.

Exadactylos, A. and J.P. Thorpe. - 2001. Allozyme variation and genetic inter-elationships between seven flatfish species (Pleuronectiformes). Zool. Linn. Soc., 132 (4): 487-499.

Felsenstein, J. - 1985. Confidence limits on phylogenies: an approach using the bootstrap. Evolution, 39: 783-791.

Felsenstein, J. - 1993. PHYLIP 3.5 (Phylogeny Inference Package). University of Washington. Seattle, Washington, USA.

Fischer, W., M. Schneider and M.L. Bauchot. - 1987. Mugilidae. In: Fiches FAO d'identification des espèces pour les besoins de la pêche. Méditerranée et Mer Noire, Zone de pêche 37. Vol: 2. pp. 1195-1200. FAO, Rome.

Golani, D. - 1994. Niche separation between colonizing and indigenous goat fish (Mullidae) along the Mediterranean coast of Israel. J. Fish. Biol., 45: 503-513.

Hureau, J.C. - 1986. Mullidae. In: P.J.P. Whitehead, M.L. Bauchot, J.C. Hureau, J. Nielsen and E. Tortonese (eds.), Fishes of the north-eastern Atlantic and the Mediterranean, pp. 877-882. UNESCO, Paris.

Konishi, M., K. Hosoya and K. Takata. - 2003. Natural hybridization between endangered and introduced species of Pseudorasbora, with their genetic relationships and characteristics inferred from allozyme analyses. J. Fish. Biol., 63: $213-231$.

Kosswig, C. - 1950. Erythraische Fishe im Mittelmeer und and Grenze der Ågais. In: A.V. Jordans and F. Peus (eds). Syllegomena biologica. Leipzig u. Wittenberg.

Mamuris, Z., A.P. Apostolidis and C. Triantaphyllidis. - 1998 Genetic protein variation in red mullet (Mullus barbatus) and striped red mullet ( $M$. surmuletus) populations from the Mediterranean Sea. Mar. Biol., 130: 353-360.

Mamuris, Z., C. Stamatisb, M. Banib and C. Triantaphyllidis. 1999a. Taxonomic relationships between four species of the Mullidae family revealed by three genetic methods: allozymes, random amplified polymorphic DNA and mitochondrial DNA. J. Fish. Biol., 55: 572-587.

Mamuris, Z., C. Stamatis and C. Triantaphyllidis. - 1999b. Intraspecific genetic variation of striped red mullet (Mullus surmuletus L.) in the Mediterranean Sea assessed by allozyme and random amplified polymorphic DNA (RAPD) analysis. Heredity, 83: 30-38.

Mamuris, Z., C. Stamatis, K.A. Moutou, A.P. Apostolidis and C. Triantaphyllidis. - 2001. RFLP analysis of mitochondrial DNA to evaluate genetic variation in Striped Red Mullet (Mullus surmuletus L.) and Red Mullet (Mullus barbatus L.) populations. Mar. Biotec., 3: 264-274.

Miller, M.P. - 1997. Tools for Population Genetic Analyses (TFPGA) 1.3: A window program for the analysis of allozyme and molecular population genetic data. Computer software dis- 
tributed by author.

Mikhov, S. - 2000. Checklist of fishes of Bulgaria. FishBase checklist modified by Stoyan Mikhov.

Moritz, C. and D.M. Hillis. - 1990. Molecular systematics: Context and controversies. In: D.M. Hillis and C. Moritz (eds.), Molecular Systematics, pp. 1-12, Sinauer Associates, Inc. Sunderland MA.

Nei, M. - 1972. Genetic distance between populations. Am. Nat., 106: 283-292.

Nei, M. - 1978. Estimation of average heterozygosity and genetic distance from a small number of individuals. Genetics, 89: 583-590.

Nelson, J.S. - 1984. Fishes of the World. In: John Wiley and Sons. New York.

Rassa, T.S. - 1983. Fish. In: V.E. Sokolov (ed.), Life of animals, Vol. 4. pp. 575. Prosveschenie, Moscow.

Sahin, T. and B. Akbulut. - 1997. Some biological characteristics of Mullus barbatus ponticus Essipov, 1927 in the Eastern Black Sea coast of Turkey. Turk. J. Zool., 21: 179-185.

Shaklee, J.B., C.S. Tamaru and R.S. Waples. - 1982. Speciation and evolution of marine species studied by the electrophoretic analysis of proteins. Pac. Sci., 36: 141-157.

Shaklee, J.B., F.W. Allendorf, D.C. Morizot and G.S. Whitt. 1990. Gene nomenclature for protein-coding loci in fish. Trans. Am. Fish. Soc., 119: 2-15.

Saitou, N. and M. Nei. - 1987. The neighbor-joining method: a new method for reconstructing phylogenetic trees. Mol. Biol. Evol., 4: 406-425

Swartz, E.R., A.F. Flemming and P.L. Mouton. - 2004. Contrasting genetic patterns and population histories in three threatened redfin species (Cyprinidae) from the Olifants River system, western South Africa. J. Fish. Biol., 64: 1153-1167.

Tortonese, E. - 1975. Fauna d'Italia, 'Osteichtyes'. In: Calderini, (ed.), Pesci Ossei, pp. 133-139. Bologna, Italy.

Turan, C., M. Caliskan and H. Kucuktas. - 2005. Phylogenetic relationships of nine mullet species (Mugilidae) in the Mediterranean Sea. Hydrobiologia, 532: 45-51.

Scient. ed.: M. Pascual

Received June 3, 2005. Accepted December 16, 2005. 